\title{
Francisco Ferreira Vilhena Alves and the Arithmetic Knowledge in the Journal The School: Official Journal of Teaching (1900-1905)
}

\author{
Iran Abreu Mendes $\mathbb{1}^{\mathrm{a}}$ \\ a Universidade Federal do Pará (UFPA), Programa de Pós-Graduação em Educação em Ciências \\ e Matemáticas, Belém, PA, Brasil.
}

\begin{abstract}
In this article, we take as reference research carried out in digitised files of the journal The School: Official Journal of Teaching, between 1900 and 1905, in search of information about elementary arithmetic knowledge for primary education present in copies of this journal. Our objective was to verify how this knowledge is reflected in the school exercises published in the journal. The theoretical-methodological contributions made to reach the objective are based on the concepts of expert, expertise, mathematical knowledge to teach and to teach, in its relations with the information about the mathematics present in the volumes of the journal that were researched. In this respect, we consider it essential to highlight the role of Francisco Ferreira de Vilhena Alves as an expert, whose insertions as editor of articles and sections of the journal, as well as from the comments on his work as an expert in education in the period in which the journal circulated, more specifically with regard to his work on the introduction of the decimal metric system in primary, secondary and especially the Normal School of Pará in the early twentieth century. The research showed that the arithmetic knowledge to be taught and to teach are materialised, interconnected, in the school exercises published in the journal, in an approach that Vilhena Alves considered adequate to guide the teacher in relation to arithmetic concepts and their teaching.

Keywords: Arithmetical knowledge; Pedagogical Journal; Expert; Primary school; History of Mathematics Education; Vilhena Alves.

\section{Francisco Ferreira Vilhena Alves e os Saberes Aritméticos na Revista A Escola: Revista Official de Ensino (1900-1905)}

\section{RESUMO}

Neste artigo, tomamos como referência uma pesquisa realizada em arquivos digitalizados da revista A Escola: Revista Official de Ensino, entre 1900 e 1905, em busca de informações sobre saberes elementares aritméticos para o ensino primário presentes em exemplares dessa revista. Nosso objetivo foi verificar como esses saberes estão refletidos nos exercícios escolares publicados na revista. Os aportes teórico-metodológicos tomados para alcançar o objetivo estão fundamentados nos conceitos de expert, expertise, saberes matemáticos a ensinar e para ensinar, em suas relações com as informações sobre as matemáticas presentes nos volumes da revista que foram pesquisados.
\end{abstract}

Corresponding author: Iran Abreu Mendes. E-mail: iamendes1@gmail.com

\begin{tabular}{|l|l|l|l|l|l|}
\hline Acta Scientiae & Canoas & Vol. 21 & N. Special & p.43-61 & June 2019 \\
\hline
\end{tabular}


A esse respeito, consideramos imprescindível destacar o papel de Francisco Ferreira de Vilhena Alves como um expert, cujas inserções como redator de artigos e secções da revista, bem como a partir dos comentários sobre seu trabalho como expert em educação no período em que a revista circulou, mais especificamente no que diz respeito ao seu trabalho voltado à introdução do sistema métrico decimal no ensino primário, no secundário e principalmente na Escola Normal do Pará no início do século XX. A pesquisa mostrou que os saberes aritméticos a ensinar e para ensinar estão materializados, de forma interconectada, nos exercícios escolares publicados na revista, em uma abordagem pela qual Vilhena Alves considerava adequada para orientar os professores com relação aos conceitos aritméticos e ao seu ensino.

Palavras-chave: Saberes aritméticos. Revistas Pedagógicas. Expert. Ensino Primário. História da Educação Matemática. Vilhena Alves.

\section{PRELIMINARY CONSIDERATIONS}

In this article we take as reference a survey conducted in some issues of the journal The School: Official Journal of Education, between 1900 and 1905, on the information related to elementary arithmetic and geometric knowledge for primary education published in this journal in order to verify how these pieces of knowledge are reflected in the school exercises published in the same journal.

The Paraense journal The School: Official Journal of Education was a pedagogical publication of monthly periodicity, founded in 1900 by the director of Public Instruction of the state of Pará, Virgílio Cardoso de Oliveira, a lawyer, poet, novelist and playwright from the state of Pará. The journal had its first issue published in August 1900. It was a periodical that aimed to address the educational issues of the State of Pará, especially those that would result in support to the work of teachers of the primary and secondary teachings of the time. Its copies circulated monthly in the state of Pará (Brazil) and, according to information highlighted in the editorial since its first number, were intended to improve the development of Public Education in the state of Pará, besides propagating, for the whole Paraense society, the advanced level of the educational area in that state of the Brazilian Federation.

In the decade of 1900, the magazine was under the leadership and responsibility of a General Board, consisting of a body of writers that involved teachers of the primary and secondary courses of the State, corresponding each writer to a matter, among those that compounded the primary course curriculum of the time. The circulation time of the journal has not yet been identified, because the numbers located in the Public Library and Archive of Pará, between 2015 and 2017, comprise the period from May 1900 to March 1905.

The editor-in-chief of the journal during the researched period was Virgil Cardodo de Oliveira, Director of Public Education of Pará and the body of writers was composed by João Ferreira de Castro Pinto, João Marques de Carvalho, Geminiano de Lyra Castro, Arthur Nobre Viana and Francisco Ferreira Vilhena Alves. These writers were responsible for the following sections: doctrines, biographies and short stories, school 
exercises, upper board, administration, legislation, news, and correspondence. In this article, we will highlight the work and publication of Francisco Ferreira Vilhena Alves in the journal above, especially in relation to mathematical knowledge, but not only about this knowledge, since the highlighted person acted in other sectors concerning local education and culture.

In this article, we associate the objectives of Morais (2017, p.66), when he emphasizes the importance and the need to analyse the production of knowledge in the pedagogical field by means of experts in education, materializing its analysis process by approaching its interrogations to investigate the ways in which specific pieces of knowledge become historically objectified in teacher education and teaching. In our case, we take as an empirical focus the information obtained in some numbers of the journal The School: Official Journal of Education that we had access to verify how the professional knowledge of Vilhena Alves was evidenced in his writings on topics such as elementary school, Portuguese teaching, elementary arithmetic, geometry and astronomy for elementary School and Normal Schools, biographical traits of intellectuals, exercises and school teaching orientations, educational legislation, among other topics that are reflected in the reports and didactic suggestions published in these numbers of the journal.

With respect to the theoretical and methodological contributions taken to achieve the objectives proposed in this article, we are based on the concepts attributed to the terms, expertise, mathematical knowledge to teach and teaching knowledge, in their relations with the information about the mathematics present in the numbers of the journal already mentioned, according to the period investigated. In this regard, we consider it essential to highlight the role of Francisco Ferreira de Vilhena Alves as an expert, whose inserts as editor of articles and sections of the journal, as well as from the comments on his work as an expert in education in the period In which the journal circulated, more specifically with regard to its work aimed at the introduction of the metric decimal system in primary school, in the secondary and especially in the Normal School of Pará at the beginning of the century XX.

It is indispensable, however, that we initially make some essential clarifications about what we incorporate in this article on the concepts of expert and expertise, because we consider that these are two concepts related to the disciplinarisation of the Education Sciences in their process of evaluating the production and development of professional knowledge to teach and teaching knowledge, in their references to mathematics, in their historical trajectory.

To get into the thematic discussion of this article, we consider it prudent to address initially the general meanings attributed to the terms expert and expertise, since they are terms of French origin directly related to experience, specialization and expertise, meaning a conjunction of skills, abilities, and knowledge generally demonstrated by a person, regarding a system or a technology. In this sense, Coelho (2015) points out that it is possible to consider that expertise is the knowledge acquired based on the study 
of a subject and the ability to apply such knowledge, resulting in experience, practice and distinction in that field of activity, that is, the term is therefore related to the skills and competencies of the individual or individuals to perform something.

Thus, Coelho (2015) reiterates that expertise is a feature of an expert, a professional recognized as a person who becomes expert in a given area, highlighted by his dexterity and competence in the execution of work. An expert is therefore an ace, a connoisseur, a person versed in the knowledge of a particular thing. It is someone with a lot of experience and practice, and therefore, considered able to give their opinion based on their knowledge.

In the process of disciplinarisation of the Sciences of Education and the emergence of an extension of these two concepts, we took the ponderations presented by Hoffstetter, Schneuwly and Freymond (2017) on this subject, when addressing the institutionalization of expertise, the specialist in education in the centuries XIX and XX and its relations as a central theme for understanding the knowledge related to teacher education. On the subject, the authors assert that,

[...] expertise is performed by people from the school environment, that is, by the teaching profession. In the clearly defined institutional conditions. The work of expertise enhances and develops strongly the knowledge that concerns them; procedures, analyses, tests become a collective product. [...] Expertise remains closely linked to the sphere of professional practice and refers to the knowledge that constitutes them. (Hoffstetter, Schneuwly, \& Freymond, 2017, p.67-68)

The highlighted fragments of the reflections presented by the authors regarding these two concepts converge directly to the indication of professional knowledge that demarcates the degrees of professional development in educational contexts that demand the mastery of such knowledge for the conduction of the educational process and the transformations of the disciplinarisation process in time and space.

It was in this sense that we consider it necessary to enter a little about who was Vilhena Alves and what his performances in various sectors related to the educational system of the state of Pará at the end of the century XIX and beginning of the century $\mathrm{XX}$ and what kind of contribution has left so that we can, in fact, consider it an expert in the sense attributed by Hoffstetter, Schneuwly, and Freymond (2017). Thus, we will discuss the following aspects related to their actions and propositions as an expert in education in Pará between 1890 and 1910, the period in which their professional insertions appear highlighted in several numbers of the journal The School: Official Journal of Education. 


\section{VILHENA ALVES AS AN EXPERT IN EDUCATION IN PARÁ}

The educator Francisco Ferreira de Vilhena Alves was born in 1847 in the city of Vigia de Nazaré (Pará); he lived almost his entire life in Bethlehem, where he died in 1912. He was considered an essential character of the public education of Pará between 1890 and 1910 due to work done by this intellectual in favour of the development of education in Pará, especially with regard to the journals published in the last decade of the Nineteenth Century and the beginning of the Twentieth Century.

Another highlight in his respect is that he was one of the founders of the Historical and Geographic Institute of Pará, one of the Founding Partners present at the foundation on May 3, 1900, a member of number 25. He served as a teacher of male classes from the first public school in the 2 nd. District of the capital, recognised as a poet, member of the Paraense Academy of Letters and collaborator of the magazines Educação $e$ Ensino (1890-1898) and A Escola (1900-1906), with several articles on education and teaching. He wrote and published textbooks for different levels of education and topics such as Portuguese Grammar, destined for the upper primary level, edited and published by Pinto Barbosa \& Cia, in 1895; First Grammar of Childhood, for Primary elementary course, also edited and published by Pinto Barbosa \& Cia in 1896; Second Grammar of Childhood, for middle Primary Education (the second edition came out in 1897 by Editora de Pinto Barbosa \& Cia); Compendium of Modern Analysis, Lexicology and Syntactic, of 1895, edited by J. B. dos Santos and printed in the Typography of the Official Gazette; Portuguese Exercises, of 1900, printed in the Typography of the Official Gazette, and Literary Selection, reading book organized with excerpts of works by Brazilian authors, including authors from Pará, dating of 1900, and edited by R. L. Bittencourt \& Cia.

Despite the contributions of Vilhena Alves in the Pedagogical Journals of Pará, we clarified that among the numbers of the journals that were part of a research conducted for the writing of this article, we found in number 5 of the journal School: Official Journal of Education (August, 1900, p.501-505) contributions of Vilhena Alves, among which an article in which the author emphasizes that the fundamental principle of teaching was to be rational, because the teacher should enable students to find out for themselves the solution of the questions that were launched and guided by the teacher, which in turn should lead to observations, inquiries, questioning and presentation of objections. Thus, the teacher could contribute to overcoming obstacles and doubts arising in the process.

It is necessary to unscrew our schools for forever the magister dixit. No one today, not even the children, is content with absolute and authoritarian principles, without being accompanied by their motives, their reason for being. The elementary notions of sciences, which childhood will drink in primary schools, are no axioms of mathematics, nor dogmas of faith, without demonstration or discussion. (Alves, August, 1900, p.503) 
The author tranversalises the entire article with argumentations and exemplifications favourable to a primary education centred on the formation of the investigative spirit of the students, considering that at that moment this was the emerging principle for the future formation of society through education at the beginning of the XX.

In the same issue of the journal, the author appears with an article that focuses on the biographical traits of maestro Carlos Gomes (Alves, August 1900, p.525-528). It is a four-page text that contains basic information about the character and his constrictions for the musical culture of the state of Para since the last three decades of the Nineteenth Century when he was living in that region until his death.

Following the same issue of the journal, we also identified the section entitled School Exercises, in which Vilhena Alves again stands out with comments and suggestions about the teaching of Portuguese, Astronomy, History, Arithmetic and Geography (Alves, August 1900 , p.529-535). With regards to the arithmetic, the author presents two suggestions of exercises to the teachers, as we will see in the next section of this article.

\section{ARITHMETIC KNOWLEDGE IDENTIFIED IN THE JOURNAL THE SCHOOL}

Regarding the arithmetic knowledge focused on the research that originated this article, we consider that, as pointed out by Hofstetter and Schneuwly (2017), these are reference knowledges, objectified by an expert to provide the incorporation of specific knowledge to teach and teaching knowledge by primary school teachers, based on the information present in the pedagogical journals published in the period investigated, as a field of knowledge that will be incorporated into the professional teaching culture that can broaden the skills, competencies, aptitudes and attitudes of the teacher in relation to what will be taught in the school. It is, therefore, with this understanding that we will comment on the arithmetic and geometric knowledge identified in the numbers of the researched journal

In this sense, in the fifth issue of the magazine The School: Official Journal of Teaching, of 1900 (5, Aug. 1900, p.532-533), in the exercises section, Vilhena Alves published a text referring to the teaching of arithmetic, as described in Figure 1, below. 


\section{Arithmetica}

PROBLKMA

Um tanque tem 8 varas de comprimento, 2 de largura $e$ 3 de profundidade. Suppondo-0 completamente cheio, qual o peso da agua em arrobas?

$$
\text { sotogito }
$$

$8 \times 2 \times 3=48$ varas cubieas.

$48 \times 1,331=63,888$ ( 63 metros cubicos e 888 decimetros).

$63,888 \times 1000=63888$ decimetros cubicos $=63888$ kilogrammos.

$63888+14,689=4349,37$

Multiplicaram-se entre si as trez dimensōes para achar 0 volume em varas cubicas: deu 48 varas cubicas.

Reduziram-se estas a metros eubicos, multiplicando pela relaçã̃o, que é 1 metro eubico e 331 decimetros: deu 63 metros cubicos e 888 decimetros.

Reduzin-se este numero de metros cubicos a decimetros, multiplicando por 1000 , porque o metro eubico tem 1000 deeimetros: deu 63888 decimetros cubicos, igual ao mesmo numero de kilogrammos, pois o kilogrammo é o peso da agua pura contida em um decimetro eubico.

Reduziu-se finalmente esse numero de kiligrammos a arrobas, dividindo pela relaçăo, que é 14 kilos e 689 grammos: deu 4349 arrobas e 37 centesimos da arroba-peso pedido.

N. B. - Ha uma pequena differença entre este resultado e a realidade: para dar o caleulo exacto, fora preciso suppôr a agua-pura, no seu maximo grán de densidade.

Figure 1. On Arithmetic (Journal A Escola, 1(5), ago. 1900). Source: Public Library and Archive of Pará (2016).

In the exercise mentioned in Figure 1, the author presents a problem situation elaborated with facts of everyday life; then, from his strategy of the resolution, demonstrate practical relations about multiplication with different quantities. The teaching approach suggested by the author was referenced in the program presented by 1900, which guides the teacher to work in a practical exercise to then present the theory.

Another similar exercise for the teaching of arithmetic was presented by Vilhena Alves in the same journal. In this exercise (Figure 2), the author presents examples of a problem that can be approached by the teacher to bring his students to identify concrete and abstract numbers in different situations related to common life, taking as 
reference an official document of the Public Instruction of 1900, which emphasizes the importance of relating to everyday situations, as the author highlighted in his article on primary education, previously mentioned, and which is published in the same number of the journal.

\title{
Arithmetica
}

\begin{abstract}
Sabemos que ha numeros abstractos e numeros concretos; aquelles vem simplismente $(13,201,26$, ete.); estes trazem uma designação (3 livros, 8 laranjas, 26 earteiras, ete.).

Os numeros concretos indicam sempre que a quantidade

foi pezada. medida ou contada, e a unidade de pezo, medida ou contrda vem explieita na designação.

Exemplo: 28 pennas, a unidade de conta é uma penna ; 36 metros de panno, a unidade de medida é o metro; 33 kilos de assuear, a unidade de pezo é o kilo ou kilogramma.
\end{abstract}

Figure 2. Exercise on arithmetic (Revista A Escola, 1(5), ago. 1900). Source: Public Library and Archive of Pará (2016).

In another issue of the magazine The School: Official Journal of Education (v.II, Oct.-Mar. 1900-1901), there is a greater volume of information on the subject of education, since the journal accumulated information about the period of approximately six months. In this expanded issue of the journal, there is a highlight to the multiple themes approached by Vilhena Alves in his expertise in education and teaching methods. In this respect the author again comments on biographical traits of intellectuals, especially Carlos Hypolito of Santa Helena Magno, a poet and natural teacher of Muaná, on the Island of Marajó, born in 1848, which stood out by the knowledge of multiple disciplinary areas such as Portuguese language, literature, literary criticism, and history of Brazil (Alves, Oct 1900-Mar. 1901, p.32-49). The composition of the organised biographical traits contains comments that seem well based on pluralistic knowledge about the expanded formation of the biographed intellectual and its biographer, thus characterising the level of expertise of Vilhena Alves to compose the text signed in this issue of the journal.

Regarding the section of the school exercises, in this issue, we identified pedagogical suggestions for the teaching of Portuguese, Geography, Astronomy, and Arithmetic, all signed by Vilhena Alves (Alves, Oct. 1900-Mar. 1901, p.50-61). To meet the specific objectives of this article, we will highlight the following excerpts extracted from the magazine. The first refers to the teaching of operations involving ordinary fractions and decimals, in which the author clarifies the identification of numerators and denominators of a fraction, their writing and their reading, as well as on the reduction of fractions at the same Denominator to perform additions and subtractions. 
In the end, it presents a general rule for carrying out such operations. We perceive, however, that the author demonstrates much expertise on the subject, as we perceive in the orientations of the previous number of the journal, in its arguments about an investigative teaching, although in this example of school exercise the rules have been enunciated without a greater emphasis on the evocation of the students' inquisitive spirit.

\section{ARITHMETICA}

Nas fracçóes ordinarias, exprimem-se e representam-se ambos os termos da fração; ex.: : (quatro setimos).

Nas frações decimaes, exprimem-se ambos os termos, mas só se representa o numerador; ex.: 0,25 (vinte e einco centesimos.)

O denominador das fraçốes decimaes é sempre dez, cem, mil, dez mil, ete.

O denominador das fraçốes ordinarias póde ser outro qualquer numero.

A reduegâa das fraccōes ordinarias ao mesmo denominador é-para sommar e diminuir.

Das fraç̧ōes decimaes-para diminuir e dividir.

A regra geral para reduzir fracgōes ordinarias ao mesmo denominador, é: multiplicar as termos de cada uma pelo denominador da outra, ou pelos denominadores das outras.

A regra para reduzir frações decimaes a mesmo denominador, é: igualar, com o acorescimo de zeros, as casas decimaes.

Figure 3. Exercise about Fractions (Revista A Escola, 1(2), out. 1900-mar. 1901). Source: Public Library and Archive of Pará (2016).

In the second part of the school exercises about arithmetic, Vilhena Alves describes the rules for the metrics reductions, when it demonstrates ways to reduce larger units to minors; how to find the price of larger units; how to relate old measure units to modern ones; how to find the price of modern measure units; how to reduce old measure units to others also old; having the price of an old measure unit, and wanting to find the price of another old unit too. 
In addition, it presents another text in which it demonstrates the conversion process of the old units of measures into modern and vice versa. These rules refer to the, probably related to his Compendium on the Metric Decimal System that dealt with the new system of measures and how to address the subject in Primary Education, Secondary Education and Normal School (Figure 4).

\section{REORAS PARA AS RBDECDOES XETRTCAS}

$$
1 \text { * }
$$

Para reduzir unidades maiores a menores, mulliplica-se 0 numerodado por 10, 100,1000 , ete.-Para reduzir unidades menores a maiores, divide-se.

Exemplo 10: 8 kilometros quantos metros sto?

Multiplieando por 1000 , isto é, acerescentando 3 zeros, achamos 8000 metros.

Ex: $2^{\circ}: 9000$ centimetros quantos metros são :

Dividindo por 100 , isto é, cortando dois zeros á direita, achamos 90 metros.

Multiplieámos por 1000, porque o kilometro tem mil metros.-Dividimos por 100, porque o metro tem 100 centi. metros.

Para achar o prego das unidades maiores, multiplica-se 0 prego da menor por 10,100,1000, ete. - Para achar 0 prego das unidades menores, divide-se o prego da maior por $10,100,1000$, ete.

Exemplo 1\%: Custando o centimetro 50 réis, qual o prego do decametro ?

Multiplicando por 1000 , teremos 50.000 réis, preģo do decametro.

Ex. $2^{*}$ : Custando o myriametro 90.000 réis, qual o preģo do metro? metro.

Dividindo 90000 por 10000 , teremos 9 réis, preģ do

Multiplieámos por 1000 , porque 0 decametro tem 1000 centimetros,-Dividimos por-10000, porque o myriametro tem 10000 metros.

Figure 5. Exercise about decimal metric system (Revista A Escola, 1(2), out. 1900-mar. 1901). Source: Public Library and Archive of Pará (2016). 
Based on the analysis made to the excerpt of pages 58 to 60 , whose fragment is highlighted in Figure 5, we perceive that the author presents only the rules for manipulation of the metric system without worrying about the possibility of questioning by the students such $\mathrm{s}$ it substantiated his work in the previous number of the journal, so as to emphasize the rational character attributed to the teaching that should be practised in schools, in that period of the beginning of the Twentieth Century. However, we realised that it was only the direct enunciate of rules, which was repeated throughout the school exercise that occupied pages 58 to 60 of this issue of the journal.

The highlight we make here and for the examples taken by the author to illustrate the rules stated, because at all times of the exercise Vilhena Alves seeks to relate nonstandardized measures to the new system of measures, as well as to the monetary system prevailing in time, in order to better understand the teacher and their use with their students.

\section{$3^{*}$}

Para reduzir medidas antigas a modernas, multiplica-se

a quantidade dada pela relação com as modernas.-Modernas

a antigas, divide-se.

Exemplo $1^{\circ}: 86$ covados quantos metros são? $56 \mathrm{~m}, 76$.

Multiplicando pela relaçấo $-0^{\mathrm{m}}, 66-$, acharemos -

Exemplo $2^{\circ}$ : 470 metros quantas jardas såo?

Dividindo pela relação $-0^{\mathrm{m}}, 91-$, acharemos 406 jardas e uma fração.

Para achar o prego das medidas modernas, divide-se 0 prego da antiga pela relação.-Das medidas antigas, multiplica-se o preço da moderna pela relação.

Exemplo $1^{\circ}$ : Custando a vara 5.000 réis, qual o preço do metro?

Dividindo 5000 pela relaģăo-1m, 1 -, acha-se $4.545^{\prime}$ réis, prego do metro.

Exemplo $2^{\circ}$ : Castando o metro 3.600 réis, qual o prego do palmo ?

Multiplieando pela relaçâo- $0 \mathrm{~m}, 22-$, acha-se 792 réis, prego do palmo.

Figure 5. Exercise over decimal metric system (Revista A Escola, 1(2), out. 1900-mar. 1901901). Source: Public Library and Archive of Pará (2016). 
In addition to demonstrating the values referring to each unit of measure that changed the author presents examples of how to perform the calculation for the measurement reductions. We emphasise that the subject addressed was part of the indications of the official program for elementary primary education of the period in which the journal was published. Another important highlight refers to the observations presented by Vilhena Alves at the end of the exercise when it draws the reader's attention to the generalisations about the metric decimal system in its relations to the measures of capacity and weight.

Another aspect related to the educational expertise of Vilhena Alves is again highlighted in his essay on elementary school, when the author arguments that primary education should be methodical, that is, the establishment of methods to teach in order to be able to fully achieve the objectives by the teacher, it must be the fundamental principle of teaching (Alves, 1900-1901, p.117-119). What the author defends in his arguments is that the teaching knowledge is fundamental in the development of the teacher's training to succeed in his teacher's year.

Also regarding the introduction of the system of measures in primary education and in the Normal School, we consider relevant what the author, in continuity, presents in the magazine, as a pedagogical contribution adequate to the insertion of this new system of measures in the school, mainly when presenting a picture (Alves, 19001901, pp.128-130), with didactic orientations to teachers, again emphasizing Vilhena Alves's expertise on these themes related to teaching.

On page 183 of the same expanded issue of the journal, we identified another suggestion of school exercise, also proposed by Vilhena Alves, when it presents problems involving the metric decimal system 


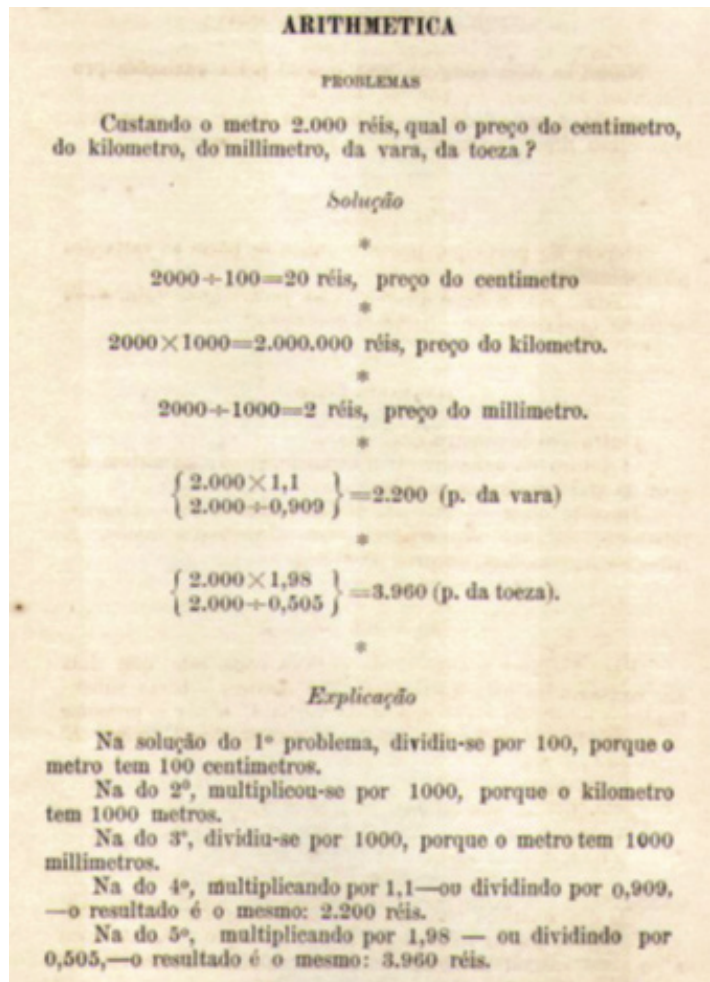

Figure 6. Arithmetic Problem (Revista A Escola, 1(2), Oct. 1900-Mar. 1901). Source: Public Library and Archive of Pará (2016).

The school exercise presented by the author is part of a problem situation, followed by a demonstration of the resolution of the problem so that the reader understands the explanation given to the resolution. We identified that in this procedure is characterised one of the teaching strategies suggested by Vilhena Alves for primary education during the decade of 1900. Our observation was concretized based on the verification of the excerpts published by the author in three articles on primary education in the journal, as well as in the analysis of the official documents on teaching, which contained guidelines for the teacher to depart from a problem situation, then presented theories related to the knowledge that he intended to be studied and learned by his students, as Vilhena Alves presented in his articles

In another text, also published in the journal A Escola: Revista official de ensino (v.II, Oct.-Mar., 1900-1901), Vilhena Alves presented his organisation of knowledge to teach and to teach the metric decimal system. In this material, the author forwards to the reader (teacher) his orientations for a conceptual and didactic approach of the metric decimal system in primary school and at the Escola Normal, with emphasis on the reductions of old to modern measures and vice versa, demonstrating that these reductions 
can also be accomplished by both multiplication and division. In the text above, the author brings several examples and explanations of how they can be performed. The text was probably elaborated from the information contained in its Compendio de Systema Metrico published, which was commented with quite detailing by José Freire Bezerril Fontenelle in his critical judgement in the form of an article published in the Revista de Educação e Ensino, in 1892, as we will comment below

\section{THE COMPENDIO DE SYSTEMA METRICO, BY VILHENA ALVES}

On this compendium elaborated and published by Vilhena Alves, we highlight a critical opinion of Bezerril Fontenelle, elaborated in 1889 and published in 1892 in the journal Educação e Ensino (II(8), ago. 1892, 125-126). According to information identified in the study, the aforementioned book was organized and published to teach theory and practice about the structure and functioning of the decimal metric system as a system of universal measurement that should be incorporated into the knowledge of All primary and secondary education students and training teachers at the Belém Normal School at the end of the Nineteenth Century and beginning of the Twentieth Century.

According to the critical study made by Bezerril Fontenelle (1892), on the aforementioned compendium, the reviewer emphasizes the importance of the work developed by Vilhena Alves in the compendium, since when using a method, considered recent for the time, It was innovative to deal with learning about measurement, and in addition the author establishes connections between a theoretical part referring to the subject, associated with another practical part, in order to make it very advantageous for those who were not very accustomed to Relations between theoretical and practical approaches to learning measurement and its arithmetic and geometric explanations connected in that type of exercise to acquire knowledge to teach and to teach in elementary school.

In This sense, the reviewer Bezerril Fontenelle (1892), comments that the lessons on the metric decimal system, coordinated by Vilhena Alves, proposed an excellent connection between theory and practice, accompanied by the necessary rules and sound examples to be put into practice, since the work was good for instruction and diffusion of the metric system and its relations with other measures belonging to more complex systems.

Synoptic frameworks are of great value, because in addition to condensing the State made in composition and decomposition, or rather, in the formation of multiples and submultiples of the metrics units of per $\mathrm{Si}$, have the great advantage of putting before the eyes the correlation that exists Between the multiples and submultiples of one for other measures, as is between the are $^{1}$ and the square meter; As well as those that exist between the different multiples and submultiples of the cubic meter compared with the litre and the gram and vice versa. (Fontenelle, 1892, p.125)

${ }^{1}$ The are was the original unit of area in the metric system, with 1 are $=100$ square metres 
In continuity to his analytical comments on the compendium of Vilhena Alves, Fontenelle praises the author for avoiding in his text, a disciplinary and doctrinal approach of the old measures and relations that exist among themselves as other authors did at that time. Specifically, regarding the subject, the reviewer mentions in his comments on the following:

Leave yourself to the routine frogmen who prefer the use of complex and fractional relationships, such as the " foot ' of inch and medium, and other linear measures (deduced from part variables of the human body and the three and a half tons from the dry wheat grain), the simple and spontaneous relations of the Always uniform division in ten, the basis of the universally used numbering system, which are deduced from a single measure - the meter - which is a length taken from the terrestrial meridian, whose invariability has been admitted scientifically. (Fontenelle, 1892, p.125)

Likewise, Fontenelle criticizes the author for the absence of some figures or graphic representations referring to measures or metric units, justifying that these forms of representation of the content would not only facilitate the comprehension of the formation and Subdivisions of the multiple and submultiples of the Metro as well as would give greater understanding of the common forms of these subdivisions. On this point, he states the following:

I manifested the gap that existed in the compendium, and Mr Vilhena Alves has promptly put together the most essential, which are intercalated in the text. Thus, although it was necessary to have more other figures, I consider the present work as complete and very useful.

A single difficulty will meet the novice who reads it, and it is the one that refers to the exact notion of the density of a body, of water, for example, that enters the definition of gram; and that of another for well comprehend the resolution of the problem of No. 217.

Not everyone is as happy as Mr Rogue Alves, who does not ignore these things from Physics, because valiantly and from the heart is delivered to the serious studies, both about Art and Science.

Can the decimal metric system of Mr. F. F. de Vilhena Alves have the acceptation that is to be expected, and be read with attention, and a lot of light will diffuse it to the indifferent who both accept the meter as the rod, little if importing that in the own metro so much if they give you gravers of $0,{ }^{\mathrm{m}} 66$, as $0,{ }^{\mathrm{m}} 68$, or yards that here are $0,{ }^{\mathrm{m}} 88$, and there of $0,{ }^{\mathrm{m}} 92$.

In 1866, I believe, it was adopted by Brazilian law the decimal metric system. Ten years later it became obligatory for its execution; However, still today, 26 years later, by an unrated Indifferentism, from the South to the North of the Empire, the 
Metro, the litre and the Kilogramme appear at the counters, to buy and sell in cubits ${ }^{2}$ or rods, in bushels, bottles and quartiles, and the ounces, pounds and tons.

This proves and justifies well the need for the apparition of good books like this which, providing an opportunity for a new reading of doctrines that are judged acceptable, useful or advantageous, lead to the conviction that is lacking - to those who are judged, - that it is certainly in the practised law, according to the uses and customs, and not in the written law, which is the characteristic expression of the acts that distinguish the truly civilised peoples.

Reform practically the bad habits, accepting only as true and just that the demonstrable dogma makes silence to convictions, and our Homeland will no longer present the sad and deplorable example [s] of the contradictions and antinomies that exist between the practised law and the written law. (Fontenelle, 1892, p.125-126)

The highlight previously given to the opinion Bezerril Fontenelle (1892), published in the Journal Education and Teaching (II(8), Aug. 1892, p.125-126), shows that the commentator aims to point out that the good definitions, allied to a clear, methodical and Insinuating, accompanied by the necessary rules and practice by means of well-chosen and developed examples, made the decimal metric system defended by Vilhena Alves in his compendium to be a good work for the education and dissemination of knowledge Measurements of the decimal metrological System as also with those of other complex metrological systems.

In this same line of analysis, the reviewer also points out that the author did well to eliminate the historical part of the content approached in the compendium, since for Bezerril Fontenelle (1892) Nothing was advanced to the essential doctrines, nor to the study of the system of measures Decimals, whose perfection alone was sufficient to impose itself preferably on all other previously adopted systematic. Similarly, the reviewer emphasised that although there had been a renovation for more than ten years and still many authors in this time did not cease to make mention to the old measures in their work. However, Vilhena Alves made different in his compendium by not bringing any mention to previous measures extinguished.

In addition, Bezerril Fontenelle positively argued about the need to publish good books such as that of Vilhena Alves that, by providing an opportunity for a new reading of doctrines that were judged acceptable, useful, or advantageous, led to the conviction that Lacked, to those who judged themselves aware of the subject, that it was certainly in the law practised, according to the uses and customs, and not in the written law, which was the characteristic expression of the acts that distinguished the truly civilized peoples.

\footnotetext{
${ }^{2}$ This and the following are ancient units of length, volume and weight employed in Brazil before the adoption of the decimal metric system.
} 


\section{CONSIDERATIONS}

Based on the information identified in the journals surveyed, we observed that in the period of 1900 to 1905 there was an expressive concern with the orientations to be disseminated in the pedagogical journals for the work of primary teachers in relation to Basic knowledge of arithmetic and that Vilhena Alves was characterized as an expert who greatly contributed to the orientations to reach the teachers. This sense, the author stood out mainly by his theoretical-methodological essays on primary education as well as on the suggestions of school exercises proposed to deal materially with the arithmetic knowledge to teach and to teach in Primary. However, its greatest contribution was achieved in the production of the Compendium on the Decimal metric system, and in the management of education as Director of the state Public Education in the same period.

We also emphasise that researching the journals made it possible to perceive that the arithmetic was caught in one of the elementary mathematical knowledge that was most present in the publications of pedagogical orientations given to teachers in Copies of the pedagogical Journal analysed. Besides this observation, it is important to highlight the significant presence of Vilhena Alves in the productions of pedagogical texts that guided the teacher how to teach elementary mathematical knowledge, because in these texts present in the journal is It is possible to emphasize that most of them complemented the education guidelines signalled in the official educational documents of the researched period.

Another conclusion pointed out by us after a reflection on the sources investigated is that based on the concepts of expert and expertise, as well as in the ponderations of Valente (2017), it was possible to realize that the knowledge to teach were more evident In these proposals of journals for their insertion in the school environments and that Vilhena Alves showed itself as one of the main highlights in the productions of these teaching orientation texts present in these researched pedagogical journals.

Likewise, the study carried out allowed us to understand how important the role of research is in historical sources such as magazines, corroborating the idea of Certeau (1982), that when we seek to know a part of the history of the past, with the purpose of Understand a little about what she treats, without making inferences with support of the present and/or with attempts to implicate in the future. Likewise, the study carried out allowed us to understand how important the role of research is in historical sources such as magazines, corroborating the idea of Certeau (1982), that when we seek to know a part of the history of the past, with the purpose of Understand a little about what she treats, without making inferences with support of the present and/or with attempts to implicate in the future.

The development of the research that originated this article was justified, mainly because it enabled the access, reflection and organization of information that could contribute to the construction of a history related to mathematical knowledge (Arithmetic), which were part of the topics of teaching and mathematical learning of the primary course in the state of Pará and the knowledge inherent in the formation of primary teachers in 
the Escola Normal de Belém, in order to allow teachers and students to understand Its essence and its development in the school environment at the end of the century XIX And the beginning of the century XX, In order to point out a little of the historical and social role of these knowledge and of the actions of the experts in education who acted in the organization of the process of disciplining these knowledge in the Public Instruction of Pará and its insertion in the classroom of the Primary Course and the Normal School.

\section{REFERENCES}

Alves, V. (1900). A Escola Primária. A Escola: Revista Official de Ensino. n.V, ago. 1900, p.501-505.

Alves, V. (1900). Traços Biográficos do Maestro Carlos Gomes. A Escola: Revista Official de Ensino. n.V, ago. 1900, p.525-528.

Alves, V. (1900). Exercícios Escolares. A Escola: Revista Official de Ensino. n.V, ago. 1900, p.529-535.

Alves, V. (1900). Arithmetica. A Escola: Revista Official de Ensino. n.V, ago. 1900, p.532-533.

Alves, V. (1900-1901). Biografia do Dr. Hypolito de Santa Helena Magno. A Escola: Revista Official de Ensino. v.II, out.-mar., 1900-1901, p.32-49.

Alves, V. (1900-1901). Exercícios Escolares. A Escola: Revista Official de Ensino v.II, out.-mar., 1900-1901, p.50-61.

Alves, V. (1900-1901). Arithmetica. A Escola: Revista Official de Ensino v.II, out.-mar., 1900-1901, p.57-60.

Alves, V. (1900-1901). A escola primária II. O ensino deve ser methodico. A Escola: Revista Official de Ensino v.II, out.-mar., 1900-1901, p.117-119.

Alves, V. (1900-1901). Exercícios Escolares. A Escola: Revista Official de Ensino v.II, out.-mar., 1900-1901, p.123-132.

Alves, V. (1900-1901). Arithmetica. A Escola: Revista Official de Ensino v.II, out.-mar., 1900-1901, p.128-130.

Alves, V. (1900-1901). Exercícios Escolares. A Escola: Revista Official de Ensino v.II, out.-mar., 1900-1901, p.178-189.

Alves, V. (1900-1901). Regras para as reduções métricas. A Escola: Revista Official de Ensino. v.II, out.-mar., 1900-1901.

Alves, V. (1891). O nosso ensino primario em 1891. Revista de Educação e Ensino v.1, n.10, dez. 1891. p.161-162.

Certeau, M. de (1982). A Escrita da História. Tradução de Maria de Lourdes Menezes. Revisão técnica [de] Arno Vogel. Rio de Janeiro: Forense Universitária, 1982.

Coelho, C. L. M. (2015). Avaliação, Expertise e processos de decisão política: o Programa 'Avaliação Externa das Escolas'em Portugal (2006-2011). Tese de Doutorado em Ciências da Educação. Faculdade de Psicologia e de Ciências da Educação da Universidade do Porto, 2015. 
Coelho, M. O. (2015). Para despertar no coração da mocidade o sentimento de amor à Pátria: o livro Seleta Literária, do professor Francisco Ferreira Vilhena Alves. Disponível em: http://sbhe.org.br/novo/congressos/cbhe7/pdf/. Acesso em 09/11/2018.

Coelho, M. O. \& Silva, R. A. da. (2018). Fazer o Mestre e o discípulo cidadão: Revistas Pedagógicas e Identidade do Professor Republicano (1900-1919). Disponível em www. histedbr.fe.unicamp.br/acer_histedbr/. Acesso em 09/11/2018.

Fontenelle, J. F. Bezerril. (1892). Compendio de systema metrico decimal do professor Vilhena Alves. Revista Educação e Ensino. v.II, n.8, ago. 1892, p.125-126.

Hofstetter, R., Schneuwly, B.; Freymoind, M. de. Penetrar na verdade da escolar para ter elementos concretos de sua avaliação: A irresistível institucionalização do expert em educação (Séculos XIX e XX). Hofstetter, R.; Valente, W. R. (Org). Saberes em Transformação: tema central da formação de professores. São Paulo: LF editorial, 2017. (p.55-112).

Hofstetter, R. \& Valente, W. R. (Org). Saberes em Transformação: tema central da formação de professores. São Paulo: LF editorial, 2017.

Morais, R. S. (2017). Experts em educação e a produção de saberes no campo pedagógico. Revista de Matemática, Ensino e Cultura - REMATEC. Ano 12/n.26/set.-dez. 2017, p.61- 70 .

Valente, W. R. (2017). A matemática a ensinar e a matemática para ensinar: os saberes para a formação do educador matemático. Hofstetter, R.; Valente, W. R. (Org). Saberes em Transformação: tema central da formação de professores. São Paulo: LF editorial, 2017. (p.201-228). 